\title{
Eco-geographical variation in the diet of the Barn Owl (Tyto alba) in mountainous areas of France
}

\author{
Guillaume Halliez ${ }^{1,2 *}$, Clémence Marie Lucie Becel ${ }^{2} \&$ Victoria \\ CANELla $^{2}$
}

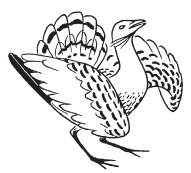

Guillaume Halliez, Clémence Marie Lucie Becel \& Victoria Canella 2015. Eco-geographical variation in the diet of the Barn Owl (Tyto alba) in mountainous areas of France. - Ornis Hungarica 23(2): 39-48. to find its pellets, it is often used to diet studies. To investigate the eco-geographical impact of mountainous areas on its diet, we conducted studies in the Jura, Alpes, Central and Pyrénées mountains and we also did pellet analysis from 8 sites in the Jura mountains. Analysis of the tooth and skull content of pellets allowed us to draw up two types of change in the diet of Tyto alba in correlation with mountain elevation. The first one concerns the Jura, Alpes and Central mountains, where the diversity of the diet declines with the increase in elevation. The second one concerns the Pyrénées mountains, where there is no change in the diversity of the diet, perhaps because of the higher diversity of small mammals caused by mediterranean influence. Thus, it seems that elevation causes a decrease in diet diversity of Tyto alba in continental mountains (Jura, Alpes and Central mountains) probably because of more homogeneous landscapes dedicated to grass production. However, in Mediterranean mountains (Pyrénées), a more diversified small mammal guild provides a constant level of diet diversity.

Keywords: Barn Owl, small mammals, mountain, mediterranean influence, continental influence

Összefoglalás A gyöngybagoly (Tyto alba) egész világon való elterjedése, és köpeteinek könnyủ fellelhetösége miatt gyakori alanya táplálkozási vizsgálatoknak. E dolgozatban a hegyvidéki környezet gyöngybagoly táplálkozására kifejtett öko-geográfiai hatásait teszteltük a Jura, az Alpok, a Francia-középhegység és a Pireneusok területén gyüjtött minták alapján, és köpet-analízist végeztünk a Jura-hegységből származó, 8 különböző területröl gyüjtött mintából. A köpetekben talált fog- és koponyamaradványok analízise alapján két csoportot lehetett elkülöníteni: a Jura, az Alpok és a Francia-középhegység területén a táplálék-diverzitása csökkent a tengerszint feletti magasság növekedésével, míg a Pireneusok területén ilyen változást nem tapasztaltunk. A különbség abból adódhat, hogy a kontinentális hegységekben (Jura, Alpok, Francia-középhegység) a tengerszintfeletti magasság növekedésével a homogénebb élőhelyek kedveznek a füfélék növekedésének, így a kisemlős diverzitás is csökken, míg a mediterrán hegységek (Pireneusok) területén egy sokkal változatosabb kisemlős közösség biztosítja a táplálék-diverzitás állandóságát.

Kulcsszavak: gyöngybagoly, kisemlősök, hegység, mediterrán hatás, kontinentális hatás

${ }^{1}$ Chrono-Environnement Laboratory, University of Franche-Comté/CNRS - 16 route de Gray, France, e-mail: guillaumehalliez25@hotmail.fr

${ }^{2}$ Universitary Group of Naturalists of Franche-Comté - 16 route de Gray, France

*corresponding author 


\section{Introduction}

Because of its worldwide distribution and the easiness to find its pellets, the Barn Owl (Tyto $a l b a$ ) is one of the most studied raptor species in the world (Michelat \& Giraudoux 1993, Begall 2005, Rasoma \& Goodman 2007). This species is able to adapt its diet to variables of its environment, such as small mammal abundance, landscape structure, landscape composition, season etc. (Taylor 2004). Its diet is particularly composed of small mammals in Europe (Bosè \& Guidali 2001, Bontzorlos et al. 2005, Bernard et al. 2010), including the Mediterranean (Leonardi \& Dell'arte 2006), and in North America (Colvin \& McLean 1986). The Barn Owl is also able to specialize on bats (Boireau 2009, Sommer et al. 2009, Roulin \& Christe 2013), insects, birds, reptiles or primates (Vargas et al. 2002, Tores \& YomTov 2003, Shehab et al. 2004, Escarlate-Tavares \& Pessôa 2005, Alivizatos et al. 2006,
Platt et al. 2009, Souza et al. 2009). Thus, it appears that the diet of the Barn Owl in spatial dimension (at world scale) is incredibly varied. There also exist some examples of temporal diet variation linked with temporal variation in prey abundance, making the Barn Owl an opportunistic predator. For example, Bernard et al. (2010) showed that during multiannual variation of grassland vole abundance (Microtus arvalis or Arvicola terrestris), the Barn Owl could adapt its diet to those food resources variation.

Although knowledge about the diet of the Barn Owl at spatial scales is good, there is less information about the variation of diet linked with variation of elevation in mountainous areas. Actually, according to Schneider (1964), we are not able to find information on Barn Owl diet above 700 meters of elevation. However, we and other authors (Libois et al. 1983) found pellets up until 1000 meters.

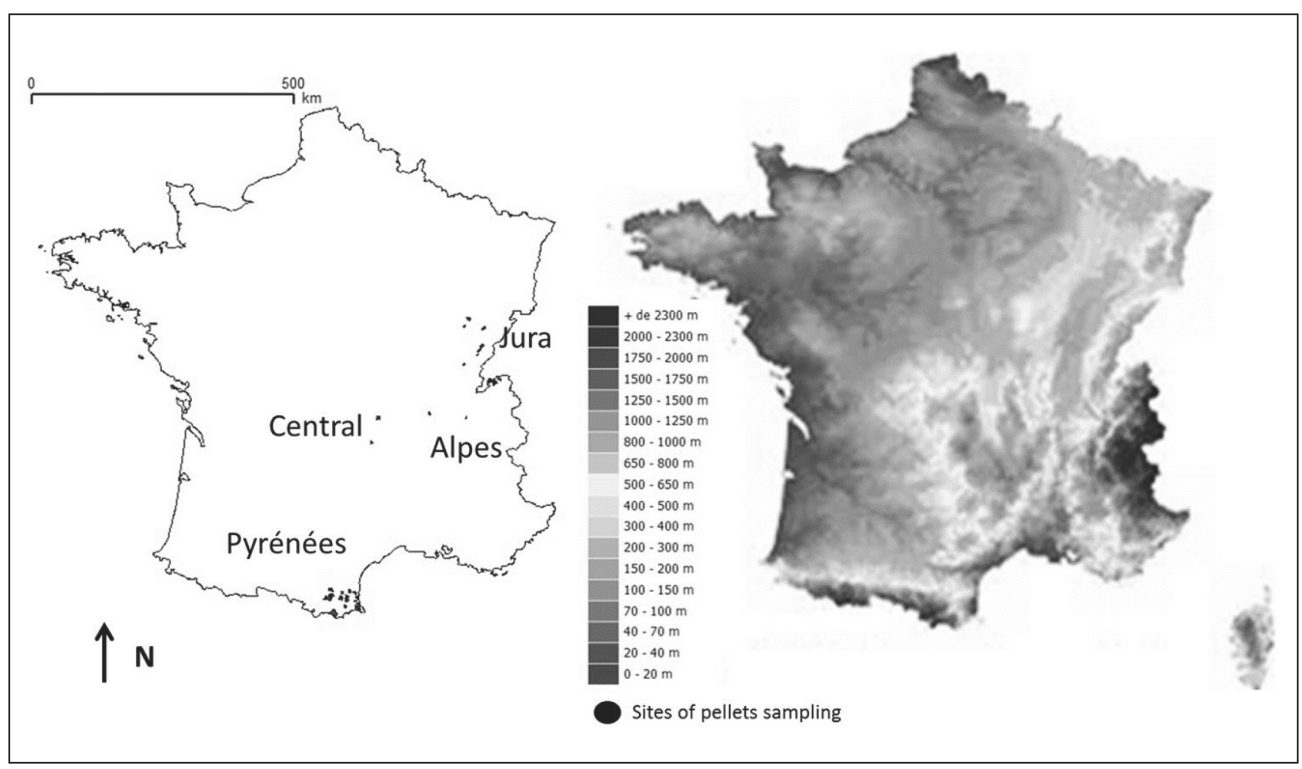

Figure 1. Localisation of the study sites in black (map on the left) and elevation in France (map on the right)

1. ábra A vizsgálati területek elhelyezkedése (bal oldali térkép) és tengerszint feletti magassága Franciaországban (jobb oldali térkép) 
We analysed pellet contents from eight sites in the Jura mountains and used data from others studies carried out in the Jura, Alpes, Central and Pyrénées mountains to study the correlation between diet diversity and elevation both in continental and Mediterranean areas.

\section{Material and methods}

\section{Study area}

The study took place in 44 municipalities of France (8 in Jura, 14 in Alpes, 2 in Central and 19 in Pyrénées) (Figure 1). The climate is continental in the Jura, Central and Alpes mountains, whereas there is a Mediterranean influence in the Pyrénées (Libois et al. 1983). The altitude ranged about 9 to 1000 meters. The distance between the sites was at least 2 kilometers, which was lower than the maximal potential distance of predation (Taberlet 1983).

\section{Pellet collection}

We collected pellets between 2010 and 2013 in several places in the Jura mountains (Table 1). We identified the small mammal species in the collected pellets by tooth and skull analysis, skull analysis, using informations from Corbet (1964), Restoin and Restoin (1972), Erome and Aulagnier (1982), Lange et al. (1986), Michelat and Giraudoux (1989) and Barčiovả and Macholản (2009) in this study. We also considered the number of individuals found in pellets in studies by Michelat and Giraudoux (1993) in the Jura mountains, Aulagnier (1982) and Rigaux and Riols (2008) in the Central mountains and Libois et al. (1983) in the Pyrénées, or the proportion of small mammal species from the study by Taberlet (1986) in the Alpes (Table 1). In this study we were not able to individualized Barn Owls to know if several individuals could use the same site.

\section{Elevation value}

The elevation of each site was obtained by using IGN French maps.

\section{Diet diversity computing}

To compute the diversity of the diet at each site, we decided to calculate a simple Shannon Diversity Index (SDI) as follows (Chao $\&$ Shen 2003): assume that there are $S$ species in a community and they are labelled from 1 to $S$. Denote the probabilities of species discovery (or relative abundance) by $\left(\pi_{1}, \pi_{2}, \ldots, \pi_{\mathrm{S}}\right)$ where $\sum_{i=1}^{s} \pi_{i}=1$

$$
S D I=-\sum_{i=1}^{S} \pi_{i} \log \left(\pi_{i}\right)
$$

\section{Statistical analysis}

To study the variation of the SDI in the Barn Owl's diet, we analysed the data from the continental mountains (Jura, Alpes and Central) separately from the Mediterranean Pyrénées mountains because of the potential difference in the small mammals species present (22 and 27 , respectively). We fitted a simple linear model, and checked the normal distribution of residuals and the homocedasticity of the variance. The null hypothesis is that the SDI of the Barn Owl's diet does not depend on the elevation in meters. 


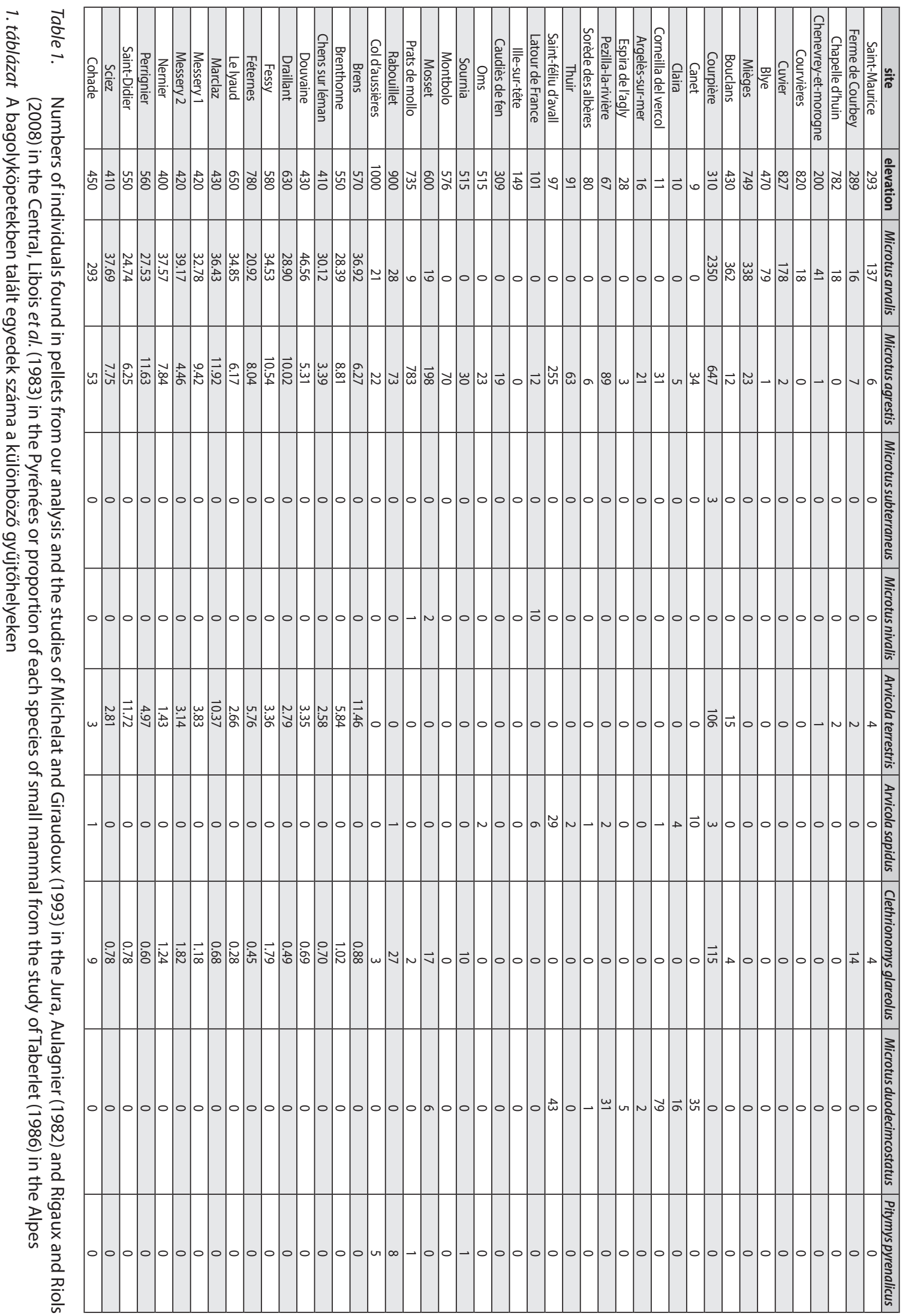




\section{Computing environment}

Data management were performed with $\mathrm{R}$ 2.12.0. software (R-Core Team 2012), using the following packages: pgirmess (Giraudoux 2012) and vegan (Oksanen et al. 2014).

\section{Results}

\section{Jura mountains diet composition}

Saint-Maurice is the most diverse site in terms of prey species, 12 species dominating the diet (in decreasing order of abundance: Microtus arvalis, Crocidura russula and Sorex coronatus/araneus). The same order of abundance was found for Courvières, Cuvier, Blye, Mièges and Bouclans. Ferme de Courbey provided only 9 species dominated by Sorex coronatus/araneus, Microtus arvalis and Clethrionomys glareolus. Chapelle d'Huin was dominated by Microtus arvalis, Sorex coronatus/araneus and Arvicola terrestris, while Chenevrey-etMorogne was dominated by Microtus arvalis, Crocidura russula and Apodemus spp.

\section{Alpes diet composition}

The Alpes diet composition was mainly dominated by Microtus arvalis, Crocidura russula and Sorex coronatus/araneus, and occasionally by species like Arvicola terrestris or Apodemus spp.

\section{Central mountains diet composition}

Both site in the Central mountains were dominated in terms of number of individuals by Microtus arvalis, Crocidura russula and Sorex coronatus/araneus.

\section{Pyrénées diet composition}

For the diet of the Barn Owl in the Pyrénées mountains, there is a lowland site with strong Mediterranean influence, where the Barn Owl feeds mainly on Mus spretus. At middle altitudes, the Barn Owl feeds on Sorex spp., Microtus arvalis, Clethrionomys glareolus and Pitymys pyrenaicus. The middle altitudes are characterized by the presence of Microtus agrestis, Apodemus spp., Crocidura spp.

\section{Elevation effect on the SDI of the Barn Owl's diet}

For the continental mountains (Jura, Alpes and Central), we found a significant negative relationship between elevation (in meters) and the SDI value (Figure 2a), following this equation: SDI value $=-0.40$ * elevation value +1.59 (ANOVA, P-value $=0.04, R^{2}=0.12$ ). However, for the Mediterranean mountain (Pyrénées), we did not find relationship between the elevation (in meters) and the SDI value (ANOVA, P-value $=0.27$ ) (Figure 2b).

\section{Discussion}

\section{Continental mountain diet composition}

Our first results indicate that the prey species at continental mountain sites are dominated by Microtus arvalis, Crocidura russu$l a$ and Sorex coronatus/araneus. This may be explained by the environmental context of those sites, i.e., they are surrounded by human-inhabited areas and open fields with crops and grass, which are their most favourable habitats (Quéré \& Le Louarn 2011). This seems to be the same 


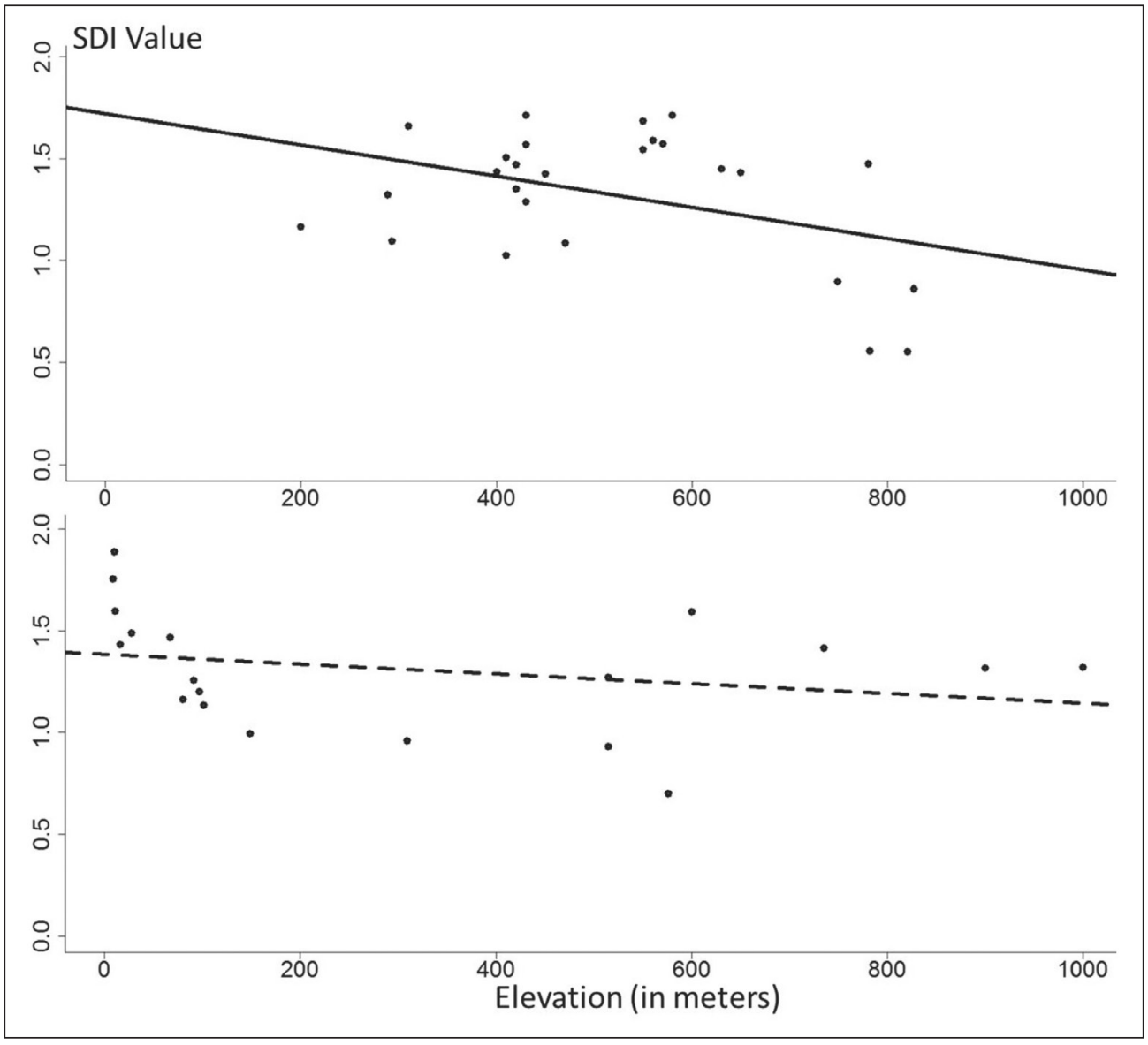

Figure 2. SDI value of the Barn Owl's diet variation regarding on elevation in continental mountains (a) and Mediterranean mountains (b)

2. ábra A gyöngybagoly táplálkozási változatosságának SDI értéke a tengerszint feletti magasság függvényében a kontinentális (a), illetve a mediterrán hegységekben (b)

for Crocidura russula, as Michelat and Giraudoux (1993) found that this species was only trapped in open fields and grove areas. Taberlet (1986) considered C. russula to be associated with open landscapes and with human-created habitats in the northern part of its distribution. Sorex coronatus/araneus, the third most abundant species in the present study, was trapped particularly in grove and hedgerows by Michelat and Giraudoux (1993). The occurrence of Mus musculus and Neomys fodiens as part of the
Barn Owl's diet could be explained by the vicinity of a village, as well as a little river, respectively.

Conversely, the site of Ferme de Courbey is different from the other sites, because it is dominated by Sorex coronatus, Microtus arvalis and Clethrionomys glareolus. The immediate vicinity of abandoned land and forests may explain the strong prevalence of Sorex coronatus and Clethrionomys glareolus, which are hedgerow- and forest specific species (Michelat \& Giraudoux 1993, 
Quéré \& Le Louarn 2011) as for the strong presence of a forested specific species: Apodemus spp. The strong prevalence of Microtus arvalis could be explained by the presence of crops and grass fields in the valley.

Moreover, as expected, we found strong prevalence of Microtus arvalis and Sorex coronatus/araneus in the pellets, as these species comprise the basic diet of the Barn Owl in Europe (Michelat \& Giraudoux 1993, Bosè \& Guidali 2001, Askew et al. 2007, Bernard et al. 2010).

\section{Mediterranean mountain diet composition}

Considering the diversity of the landscapes, the Pyrénées-orientales area is one of the most varied in France. Vegetation maps show habitats ranging from coastline to medium-high mountains. The eumediterranean status of the area is indicated by the presence of Mus spretus and the absence of Microtus arvalis or Sorex spp. There also exist submediterranean areas with simultaneous presence of Mus spretus and Sorex spp. Microtus duodecimeostatus, Suncus etruscus and Crocidura suaveolens presence claimed for Mediterranean areas. Microtus duodecimeostatus characterized the presence of crop fields. The abundance of the three species of Crocidurinae, especially Crocidura russula, characterized some micro-habitats, like dykes (Fons 1975, Genoud \& Hausser 1979).

\section{Elevation effect on the SDI value of the Barn Owl's diet indicates two eco- geographical trajectories: continental and Mediterranean mountains}

Our results show that it is possible to differentiate between French continental and Mediterranean mountain areas using SDI values of prey diversity in the Barn Owl's pellets and relate these to elevation: the SDI decreases with increasing elevation in continental mountains and does not change in Mediterranean areas. As for continental mountains, two variables could explain the decrease of diet diversity when elevation increases: i) landscape composition, creating outbreaks of certain prey species, and ii) limited number of species. Indeed, in mountainous areas of France, land use policy led to an agricultural specialization towards grass production and towards larger parcel sizes (López-i-Gelats et al. 2011). This promoted the emergence of multiannual vole (Arvicola terrestris and Microtus arvalis) population fluctuations at large spatial and temporal scales (Delattre et al. 1992, Giraudoux et al. 1997, Delattre et al. 2006, Foltête et al. 2008, Berthier et al. 2013). Delattre et al. (1992) showed that damages due to multiannual fluctuation patterns of the Common Vole increases with the Ratio of Permanent Grassland to Farmland (RPGF). For Arvicola terrestris, Saucy (1994), in Switzerland, found cyclic changes in population abundance with statistically significant periods ranging between 5 and 7 years. In Franche-Comté, France, Giraudoux et al. (1997) found a 5-6 year cycle that was established since the early ' 70 s after the expansion of permanent grassland in farmland at a regional scale. This specialization toward grass production could lead to a very important population increase of Arvicola terrestris and Microtus arvalis. Also, Bernard et al. (2010) showed that during multiannual variation of grassland vole abundance, rodent frequency in the diet of Tyto alba ranged from 54\% to 61\%, with Arvicola terrestris and Microtus arvalis as dominant preys, and that the proportion of Sorex spp. could reach $34 \%$. 
This means that in the continental sites of the present study, above 700 meters, three species could represent almost $100 \%$ of the diet of the Barn Owl because of landscape homogeneity (grassland). Thus, the agricultural specialization creating landscape homogeneity and vole outbreaks in grassland areas could be an explanation of the decrease of SDI value in continental mountains. Another possibility is that the number of potential prey species is 22 . Indeed, as our continental sites reach only 820 meters at the maximum of elevation the diet of the Barn Owl could not account the presence of new species as Microtus nivalis, Sorex alpinus, Sorex antinorii, Apodemus alpicola. In the Mediterranean Pyrénées mountains, we observed that the SDI value remained stable in lowland, as well as in mountainous areas. The first explanation for that can be that this area is not concerned by outbreaks of Water Vole or Common Vole, keeping the diet of the Barn Owl relatively diversified. Moreover, while some species are present in coastline areas (Microtus duodecimeostatus, Mycromis minutus, Mus spretus, Sorex coronatus/araneus) (Libois et al. 1983), they are absent in the mountains and are replaced by mountain species (Microtus arvalis, Microtus nivalis, Clethrionomys glareolus, Pitymys pyrenaicus, Sorex minutus, Neomys fodiens) (Quéré \& Le Louarn 2011).

\section{References}

Alivizatos, H., Goutner, V., Athanasiadis, A. \& Poirazidis, K. 2006. Comparative temporal prey use by Barn Owl (Tyto alba) and Little Owl (Athene noctua) in the Evros Delta, northeastern Greece. - Journal of Biological Research 6: 177-186.

Askew, N. P., Searle, J. B. \& Moore, N. P. 2007. Agri-environment schemes and foraging of Barn Owls Tyto alba. - Agriculture, Ecosystems and

\section{Conclusion}

To study the eco-geographical impact of mountainous areas on the Barn Owl's diet, we used the results of some studies from the Jura, Alpes, Central and Pyrénées mountains and we also carried out pellet analysis at 8 sites in the Jura mountains. Our results indicate that there are two dietary types of Tyto alba in correlation with elevation. The first one is typical of the Jura, Alpes and Central mountains, were the diversity of the diet declines with the increase in elevation. The second is typical of the Pyrénées mountains, where the diversity of the diet remains stable perhaps because of the higher diversity of small mammals as a result of Mediterranean influence. Finally, we propose that elevation makes diet diversity of Tyto alba decrease in continental mountains probably because of more homogeneous landscapes due to specialization towards grass production. In Mediterranean mountain areas, the influence of a more diverse small mammal guild contributes to a constant level of diet diversity.

\section{Acknowledgement}

We would like to express our gratitude to referees and József Vuts who made the language corrections for the manuscript.

Environment 118: 109-114. DOI: 10.1016/j. agee.2006.05.003

Aulagnier, S. 1982. Notes sur le regime alimentaire de la chouette effraie (Tyto alba) dans une localité de Haute-Loire [Note on diet of Barn Owl (Tyto alba) in Haute-Loire village]. - Le Grand Duc 19: 15-16. (in French)

Barčiovả, L. \& Macholản, M. 2009. Morphometric key for the discrimination of two wood mice 
species, Apodemus sylvaticus and A. flavicollis. Acta Zoologica Academiae Scientiarum Hungaricae 55(1): 31-38.

Begall, S. 2005. The relationship of foraging habitat to the diet of Barn Owls (Tyto alba) from central Chile. - Journal of Raptor Research 39(1): 97101.

Bernard, N., Michelat, D., Raoul, F., Quéré, J. P., Delattre, P. \& Giraudoux, P. 2010. Dietary response of Barn Owls (Tyto alba) to large variations in populations of Common Voles (Microtus arvalis) and European Water Voles (Arvicola terrestris).Canadian Journal of Zoology 88: 416-426. DOI: 10.1139/Z10-011

Berthier, K., Piry, S., Cosson, J. F., Giraudoux, P., Foltête, J. C., Defaut, R., Truchetet, D. \& Lambin, X. 2013. Dispersal, landscape and travelling waves in cyclic vole populations. - Ecology Letters 17(1): 53-64. DOI: 10.1111/ele.12207

Boireau, J. 2009. Problèmes posés par l'effraie des clochers Tyto alba dans cinq colonies de reproduction de grand rhinolophe Rhinolophus ferrumequinum (Schreber, 1774) en Bretagne occidentale [Problems caused by Barn Owl Tyto alba presence in five settlements of Rhinolophus ferrumequinum (Schreber, 1774) in occidental Britain]. - Le Rhinolophe 18: 43-49. (in French with English Summary)

Bontzorlos, V. A., Peris, S. J., Vlachos, C. G. \& Bakaloudis, D. E. 2005. The diet of Barn Owl in the agricultural landscapes of central Greece. - Folia Zoologica 54(1-2): 99-110.

Bosè, M. \& Guidali, F. 2001. Seasonal and geographic differences in the diet of the Barn Owl in an agro-ecosystem in northern Italy. - Journal of Raptor Research 35(3): 240-246.

Chao, A. \& Shen, T. J. 2003. Nonparametric estimation of Shannon's index of diversity when there are unseen species in sample. - Environmental and Ecological Statistics 10: 429-443. DOI: 10.1023/A:1026096204727

Colvin, B. A., McLean, E. B. 1986. Food habits and prey specificity of the Common Barn Owl in Ohio. - Ohio Journal of Science 86: 76-80.

Corbet, G. B. 1964. The identification of British mammals. - British Museum London, pp. 46

Delattre, P., Clarac, R., Melis, J. P., Peydell, D. R. J. \& Giraudoux, P. 2006. How moles contribute to colonization success of Water Voles in grassland: implications for control. - Journal of Applied Ecology 43: 353-359. DOI: 10.1111/j.13652664.2006.01134.x

Delattre, P., Giraudoux, P., Baudry, J., Musard, P., Toussaint, M., Truchetet, D., Stahl, P., Poule, M. L., Artois, M., Damange, J. P. \& Quéré, J. P. 1992.
Land use patterns and types of Common Vole (Microtus arvalis) population kinetics. - Agriculture, Ecosystems and Environment 39: 153-169.

Erome, G. \& Aulagnier, S. 1982. Contribution à l'identification des proies de rapaces [Contribution to the raptor's prey identification]. - Bièvre 4: 129-135.

Escarlate-Tavares, F. \& Pessôa, L. M. 2005. Bats (Chiroptera, Mammalia) in Barn Owl (Tyto alba) pellets in northern Pantanal, Mato Grosso, Brazil. Mastozoologia Neotropical 12(1): 61-67.

Foltête, J. C., Berthier, K. \& Cosson, J. F. 2008. Cost distance defined by a topological function of landscape. - Ecological Modelling 210(1-2): 104114. DOI: $10.1016 /$ j.ecolmodel.2007.07.014

Fons, R. 1975. Premières données sur l'écologie de la Pachyure étrusque, Suncus etruscus (Savi, 1822) et comparaison avec deux autres Crocidurinae: Crocidura russula (Hermann, 1780) et Crocidura suaveolens (Pallas, 1811), (Insectivora, Soricidae) [First data on Suncus etruscus (Savi, 1822) ecology and comparison with two others Crocidurinae: Crocidura russula (Hermann, 1780) and Crocidura suaveolens (Pallas, 1811), (Insectivora, Soricidae)]. - Revue d'Ecologie (Vie Milieu) 25: $315-$ 360. (in French)

Genoud, M. \& Hausser, J. 1979. Ecologie d'une population de Crocidura russula en milieu rural montagnard (Insectivora, Soricidae) [Crocidura russula (Insectivora, Soricidae) population ecology in rural mountain ecosystem]. - Revue d'Ecologie (Terre et Vie) 33: 539-554. (in French with English Summary)

Giraudoux, P. 2012. pgirmess: Data analysis in ecology. - R package version 1.5.2.

Giraudoux, P., Delattre, P., Habert, M., Quéré, J. P., Deblay, S., Defaut, R., Duhamel, R., Moissenet, M. F., Salvi, D. \& Truchetet, D. 1997. Population dynamics of fossorial Water Vole (Arvicola terrestris scherman): a land use and landscape perspective. - Agriculture, Ecosystems and Environment 66: 47-60.

Lange, R. A., Van Winden, P., Twisk, J., De Laender, \& Speer, C. 1986. Zoogdieren van de Benelux Herkenning en onderzoek, met uitzondering van de hoefdieren en de zeezoogdieren [Mammals of the Benelux recognition and research, with the exception of marine mammals and ungulates]. - ERLA, Amsterdam, pp. 193 (in Dutch)

Leonardi, G. \& Dell'Arte, G. L. 2006. Food habits of the Barn Owl (Tyto alba) in a steppe area of Tunisia. - Journal of Arid Environments 65: 677-681. DOI: $10.1016 /$ j.jaridenv.2005.10.007

Libois, R. M., Fons, R. \& Saint-Girons, M. C. 1983. Le régime alimentaire de la chouette effraie, Tyto 
alba, dans les Pyrénées-orientales. Etude des variations écogéographiques [Barn Owl's diet in Pyrénées-orientales. Eco-geographical variation study]. - Revue d'Ecologie (Terre Vie) 37: 187-217. (in French with English Summary)

López-i-Gelats, F., Milán, M. J. \& Bartolomé, J. 2011. Is farming enough in mountain areas? Farm diversification in the Pyrenees. - Land Use Policy 28: 783-791. DOI: 10.1016/j.landusepol.2011.01.005

Michelat, D. \& Giraudoux, P. 1989. Répartition des mammifères proies de la chouette effraie en Franche-Comté [Barn Owl's mammal preys distribution in Franche-Comté]. - Falco 23: 12-37. (in French)

Michelat, D. \& Giraudoux, P. 1993. Relation proiesprédateur-paysage chez la chouette effraie Tyto alba pendant l'élevage des jeunes [Prey-predator-landscape relationship for Barn Owl Tyto alba during rearing]. - Alauda 61(2): 65-72. (in French with English Summary)

Oksanen, J., Blanchet, F. G., Kindt, R., Legendre, P., Minchin, P. R., O’Hara, R. B., Simpson, G. L., Solymos, P., Stevens, M. H. H. \& Wagner, H. 2014. Vegan: Community Ecology Package. R package version 2.0-10 [online]. Available from http://CRAN.R-project.org/package=vegan.

Platt, S. G., Rainwater, T. R., Leavitt, D. J. \& Miller, S. M. 2009. Diet of Barn Owls (Tyto alba) in northern Belize. - The Southwestern Naturalist 54(1): 104-107. DOI: 10.1894/MH-43.1

Quéré, J. P. \& Le Louarn, H. 2011. Les rongeurs de France, faunistique et biologie [French rodents, systematic and biology]. - Quae, Versailles, pp. 311 (in French)

Rasoma, J. \& Goodman, S. M. 2007. Food habits of the Barn Owl (Tyto alba) in spiny bush habitat of arid southwestern Madagascar. - Journal of Arid Environments 69: 537-543. DOI: 10.1016/j.jaridenv.2006.10.004

R Core Team 2012. R: A language and environment for statistical computing. - R Foundation for Statistical Computing, Vienna, Austria

Restoin, J. A. \& Restoin, J. 1972. Identification des proies de rapaces d'après les restes trouvés dans les pelotes de réjection [Identification of raptor's preys from remains in pellets]. - CRDP Besançon, pp. 14 (in French)

Rigaux, P. \& Riols, C. 2008. Régime alimentaire de l'effraie des clochers (Tyto alba) à Courpière, Val de Dore (Puy-de-Dôme) [Barn Owl diet in Courpières, Val de Dore (Puy-de-Dôme)]. - Le Grand-Duc 73: 27-29. (in French)
Roulin, A. \& Christe, P. 2013. Geographic and temporal variation in the consumption of bats by European Barn Owls. - Bird Study 60(4): 561-569. DOI: 10.1080/00063657.2013.847051

Saucy, F. 1994. Density dependence in time series of the fossorial form of the Water Vole, Arvicola terrestris. - Oikos 74: 381-392.

Schneider, W. 1964. Die Schteiereule [The Barn Owl]. - Neue Brehm Bücherel. Helt 340, Wittenberg, pp. 104 (in German)

Shehab, A., Daoud, A., Kock, D. \& Amr, Z. 2004. Small mammals recovered from owl pellets from Syria (Mammalia: Chiroptera, Rodentia). - Zoology in the Middle East 33: 27-42. DOI: 10.1080/09397140.2004.10638061

Sommer, R., Niederle, M., Labes, R. \& Zoller, H. 2009. Bat predation by the Barn Owl Tyto alba in a hibernation site of bats. - Folia Zoologica 58(1): 98-103.

Souza, D. P., Asfora, P. H., Lira, T. C. \& Astùa, D. 2009. Small mammals in Barn Owl (Tyto al$b a$ - Aves, Strigiformes) pellets from Northeastern Brazil, with new records of Gracilinanus and Cryptonanus (Didelphimorphia, Didelphidae). - Mammalian Biology 75: 370-374. DOI: 10.1016/j.mambio.2009.08.003

Taberlet, P. 1983. Evaluation du rayon d'action moyen de la chouette effraie, Tyto alba (Scopoli, 1769), à partir de ses pelotes de réjection [Evaluation of the distance of foraging for the Barn Owl, Tyto alba (Scopoli, 1769), from pellets]. - La Revue d'Ecologie (Terre et Vie) 38: 171-177. (in French with English Summary)

Taberlet, P. 1986. Etude de l'écologie des micromammifères à partir des pelotes de réjection de Tyto alba (Scopoli, 1769), application au Bas-Chablais (Haute-Savoie - France) [Small mammals ecology from Tyto alba (Scopoli, 1769) pellets, application to the Bas-Chablais (Haute-Svoie - France)]. - La Revue d'Ecologie (Terre et Vie) 41: 193217. (in French with English Summary)

Taylor, I. 2004. Barn Owls, predator-prey relationships and conservation. - Cambridge University Press, New York, pp. 311

Tores, M. \& Yom-Tov, Y. 2003. The diet of the Barn Owl Tyto alba in the Negev desert. - Israel Journal of Zoology 49: 233-236. DOI: 10.1560/JU3EEWK4-13QY-CGRF

Vargas, J., Landaeta, C. A. \& Simonetti, J. A. 2002. Bats as prey of Barn Owls (Tyto alba) in a tropical savanna in Bolivia. - Journal of Raptor Research 36(2): 146-148. 